\title{
Historic Frequency and Severity of Fire in Whitebark Pine Forests of the Cascade Mountain Range, USA
}

\author{
Michael P. Murray ${ }^{1, *}$ and Joel Siderius ${ }^{2}$ \\ 1 British Columbia Ministry of Forests, Lands, Natural Resource Operations and Rural Development, \\ \#401-333 Victoria Street, Nelson, BC V1L 4K3, Canada \\ 2 National Park Service, 12795 W. Alameda Parkway, Lakewood, CO 80228, USA; joel_siderius@nps.gov \\ * Correspondence: michael.murray@gov.bc.ca
}

Received: 24 November 2017; Accepted: 28 January 2018; Published: 7 February 2018

\begin{abstract}
Whitebark pine (Pinus albicaulis Engelm.) is a foundation species of high elevation forest ecosystems in the Cascade Mountain Range of Oregon, Washington, and British Columbia. We examined fire evidence on 55 fire history sites located in the Cascade Range. To estimate dates of historic fires we analyzed 57 partial cross-sections from fire-scarred trees plus 700 increment cores. The resulting 101 fire events indicate fire has been a widespread component of Cascadian whitebark pine stands. Results are site specific and vary considerably. Whitebark pine stands appear to burn in a variety of severities and frequencies. Sites where fire intervals were detected ranged from 9 to 314 years, with a median of 49 years, and averaging 67 years. Fire intervals shortened significantly with higher latitudes. In assessing the most recent fire event at each site, overall, 56 percent burned as stand replacing events. In the 20th century, the number of fires diminished significantly. Due to conservation imperatives, re-introducing fire should be undertaken with extreme care to avoid substantial mortality of this endangered species.
\end{abstract}

Keywords: whitebark pine; fire history; Cascade Mountains

\section{Introduction}

Whitebark pine (Pinus albicaulis Engelm.) is widely distributed at high elevations in the Cascade Mountain range of the Pacific Northwest, USA and southwest British Columbia. As a foundation species at many locations, whitebark pine offers large nutritious seeds to wildlife, regulates summer snowmelt and provides aesthetic appeal to recreationists [1,2]. Most populations are in decline from the introduced pathogen, white pine blister rust (Cronartium ribicola J.C. Fisch) and mountain pine beetle (Dendtroctonus ponderosae Hopkins) epidemics [3]. Endangered species status is pending in the USA [4] but authorized in Canada [5].

As a natural disturbance agent, fire plays dualistic roles, both promoting and negatively impacting whitebark pine across its natural range. Mature trees have intermediate bark thickness and characteristic upswept limbs that protect their crowns from ground surface flames. Whitebark pine often survive low-intensity fires, whereas its most common competing tree species are less fire adapted [6]. Effective curtailment of fire due to land management policies has led to competitor replacement of whitebark pine at locations in the Rocky Mountains and possibly elsewhere $[7,8]$. Fire can also promote whitebark pine regeneration by creating forest openings conducive to seed caching by Clark's nutcracker (Nucifraga Columbiana Wilson), the primary agent for seed dispersal [9]. In contrast, moderately intense fires commonly kill all size classes of whitebark pine [10]. Due to increasing frequency and intensity of hot dry summers in western North America, conifers may be increasingly prone to amplified fire effects as well as climatic stress as a predisposing factor to fire-induced mortality [11]. This threat is poorly understood for whitebark pine communities. 
In the Pacific Northwest, the limited fire history research has typically regarded subalpine forests to burn severely but infrequently [12]. However, Agee [13] compiled data from numerous sources, concluding that whitebark pine forests burn much more frequently than subalpine fir (Abies lasiocarpa Hook.), subalpine larch (Larix lyallii Parl.), and mountain hemlock (Tsuga mertensiana Bong.).

Fire regimes have been studied throughout the Pacific Northwest and Intermountain West [13], however, research is lacking for whitebark pine forests of the Cascade Mountains. Knowledge of fire regimes enables forest managers to plan and make informed decisions. The vast majority of whitebark pine fire regime knowledge has been gained from the Rocky Mountains of interior western North America. Low severity (non-stand replacing) fire frequency was estimated between 2 and 78 years $[14,15]$ but Barrett [16] estimated longer fire intervals (66-204 years) in Yellowstone National Park which were comparable to findings in the West Big Hole Range of Montana and Idaho [17]. High severity (stand replacing) estimates range from 300-400 years [16,18]. Arno [14] indicated that fires commonly burned less intensively at the upper subalpine zone. Barrett [16], Brown and others [19] and Murray [17] found evidence for all classes of severity in the whitebark pine forests that they sampled.

In general, Cascadian whitebark pine communities support more conifer species, endure a maritime climate, and tend to be more isolated into smaller stands than Rocky Mountain populations. The objective of this study was to investigate and provide an initial approximation of two primary aspects of historic fire regimes associated with Cascadian whitebark pine communities-frequency and severity. Our results can enhance information available for fire planning and management of these forests.

\section{Materials and Methods}

The study area straddles the crest of the Cascade Mountains of Washington and Oregon (Figure 1). The northernmost extent of the study area is at Tiffany Peak approximately $24 \mathrm{~km}$ south of the Canadian border. Our analysis extends south to Pelican Butte near the Oregon-California border. We focused field study at three separate locations. The Southern Oregon Unit is the warmest and driest study location, encompassing Crater Lake National Park, Fremont-Winema National Forest, and Deschutes National Forest. The Mount Rainier Unit consists of sites at Mount Rainier National Park and the Okanogan-Wenatchee National Forest and receives the deepest snow depths. The North Cascades Unit consisted of sites at Lake Chelan National Recreation Area and Okanogan-Wenatchee National Forest.

In the northern Cascades, whitebark pine most often occurs with Engelmann spruce (Picea engelmannii Parry ex Engelm.), subalpine fir, lodgepole pine (Pinus contorta Douglas ex Louden), and subalpine larch, and is less frequently associated with Douglas-fir (Pseudotsuga menzieii (Mirb.) Franco) and yellow cedar (Callitropsis nootkatensis D. Spach). Subalpine fir is the most common co-dominant in the Mount Rainier area. Associates in the southern Cascades are mountain hemlock, Shasta red fir (Abies magnifica $x$ shastensis Lemmon), and lodgepole pine.

Whitebark pine stands were identified using existing maps, consulting with local experts, and topographic analysis of the expected range of whitebark pine. We only sampled sites within a day's round-trip hike from a road. Stands were eligible for sampling where $25 \%$ or greater canopy coverage of whitebark pine was observed in relation to other tree species. While most stands exhibited clear signs of historic fires (i.e., fire scars, charcoal, distinct age cohorts), we also sampled sites with no readily apparent evidence. Circular plots $\left(400 \mathrm{~m}^{2}\right)$ were located to represent overall characteristics of stands (e.g., size structure, understory composition/cover). Plots occurred between elevations of $1675 \mathrm{~m}$ at Little Bald Mountain, in Washington to nearly $2700 \mathrm{~m}$ at Mt. Scott in southern Oregon. All sampling was conducted during 2003-2004.

Fire history sampling methodology was adapted from Arno and Sneck [20] and involved evaluating stand age structure and tree fire scars to detect historic fire events. Exposed fire scars are triangular, with the wound beginning at or below ground level [21,22]. The scar is typically found on the leeward or uphill side of trees where heat concentrates during a fire event and flame heights are greater due to less wind dispersing the heat from the passing fire [22]. Fire scars can be identified by 
having uniform margins, in contrast to scars left by beetles or wildlife which often exhibit irregular and furrowed patterns along the edges of the scar face [21]. During fieldwork, extreme care was taken to differentiate between fire scars and wounds left behind from other agents such as mountain pine beetle, porcupine, bear, bole scrapes or other types of mechanical injury. Only scars that exhibited the highest degree of probability were sampled and consequently used in analysis of fire intervals.

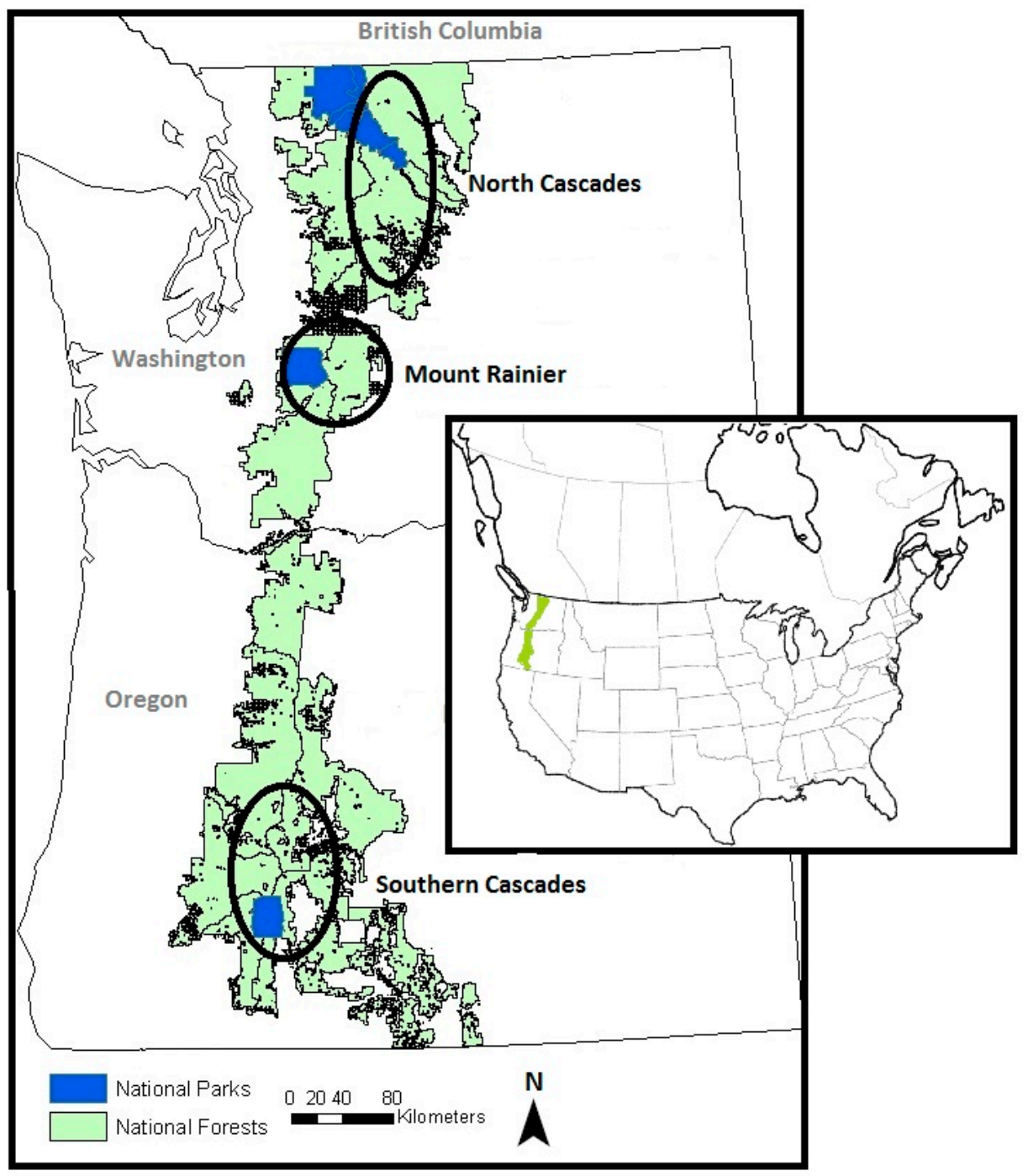

Figure 1. Location of three analysis areas where fire history plots were sampled in the Cascade Mountain Range.

Samples of fire scars were extracted using a chainsaw to collect partial cross-sections [14] (Figure 2). Heyerdahl and McKay [23] demonstrated that sampling living fire-scarred trees with partial cross-sections is an effective non-lethal means of obtaining valuable fire history data. In the event a downed snag was found, a complete stem cross-section was sampled. For each fire scar tree location, a GPS waypoint and digital photograph were taken. Additionally, characteristics such as diameter at breast height (DBH), description of site, tree vigor, and other information that may help with future analysis (i.e., char on scar face) were documented in the field notes. The average tree height and height to live crown ratio were estimated per species for dominant trees. Charcoal is often regarded as the most fundamental indicator that fire has been present in an ecosystem $[13,24]$. Thus, presence or absence of charcoal was documented for each site. 


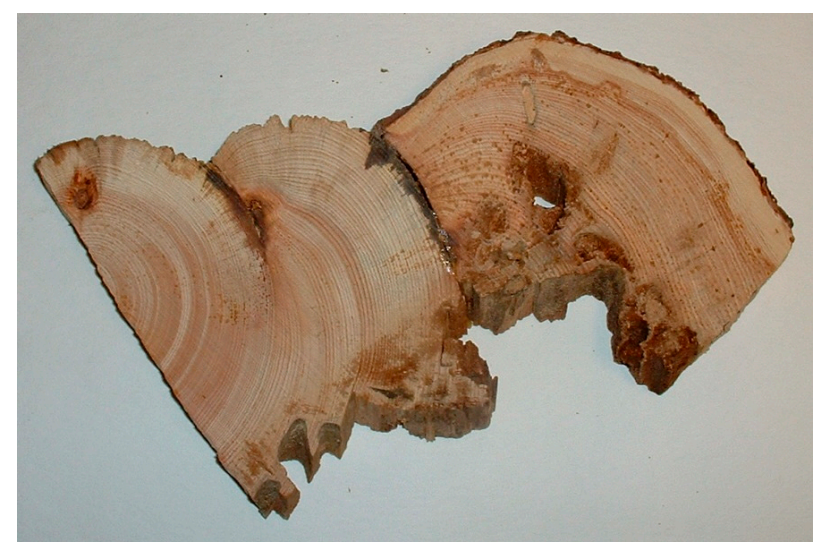

Figure 2. A partial cross-section from a whitebark pine tree with two fire scars extracted using chainsaw.

To estimate stand age structure, two trees per species were sampled for each size class with an increment borer to estimate age class. Size classes were defined as DBH of $\leq 10 \mathrm{~cm}$ ), $10-20 \mathrm{~cm}$, $20-30 \mathrm{~cm}$, and $30 \mathrm{~cm}$ and greater. Trees were cored at $40 \mathrm{~cm}$ above the ground. Whenever possible, trees were sampled from the side-slope to ensure standard sampling protocol. An age to coring height correction was added to the age of each tree. This correction factor was based on selecting a $40 \mathrm{~cm}$ tall seedling at ground level from an open microsite and aging the tree. This was done for each species at each site.

We noted the plant community for each plot based on the observed dominant overstory (typically whitebark pine) and understory species at each specific plot. Overstory and understory compositions are readily recognized and commonly mapped by land managers and fire planners. A variety of understory types can indicate different historic fire regimes, even within a single overstory community [25]. The percent cover of dominant ground cover (i.e., herbaceous plants, rock, gravel, litter, duff, etc.) was recorded on each plot. All trees less than $2 \mathrm{~m}$ in height were regarded as seedlings, and were counted per quarter plot. To estimate the severity of historic fires, an inventory of down and dead was performed. All trees with their base originating in the plot were considered for the down and dead survey. Down and dead trees were measured at breast height, assigned a rot class, and based on the rot class a time since death was estimated. Fire was classified as high severity (stand replacing) or low severity (non-stand replacing) based on field observations and subsequent tree-ring analysis for each plot. If we estimated that there was more than a single tree that survived the fire within a $400 \mathrm{~m}^{2}$ plot, the fire was classified as low severity [26].

Partial cross-sections and increment core samples were mounted and sanded with progressively finer sandpaper (60-600 grit). If a sample did not have a pith, a pith locator was used to estimate the number of rings absent $[27,28]$. After processing the samples, partial cross-sections collected from dead trees were cross-dated to assign a year of death and fire event [29-31]. Partial cross-sections were cross-dated against existing regional chronologies of whitebark pine when available. Whitebark pine chronologies were obtained from the International Tree Ring Databank for the Mount Rainer area [32] and North Cascades [33]. Since no published whitebark pine chronologies were available from the Southern Oregon Unit, we compiled a chronology from whitebark pine cores previously collected in Crater Lake National Park.

An even-aged stand structure is indicative of a forest disturbance event and therefore useful for dating fire events, especially where fire scars are lacking [21]. Stand ages were estimated based on our sample of two trees per species, per size class. Ages of the remaining uncored trees in each plot were estimated based on the specific age-growth curves determined from the sampled trees on the respective plot. Dating of fires using dendrochronological evidence was supplemented with administrative fire records including federal fire atlases. To summarize fire frequency, we calculated the multiple site average fire interval (MSAFI). Barrett and Arno [21] recommended MSAFI as a technique for 
characterizing fire history data encompassed from separate sampled sites based on both age class and fire scar data. Where only a single fire was detected (incomplete interval), a simple time-since-last-fire value was assigned to each respective plot. This value should be considered the number of years between two consecutive fires (interval) if a fire were to occur during our sampling year (2003 or 2004). Thus, this value represents the minimum number of years necessary for a complete interval. We calculated MSAFI for each whitebark pine community type as defined by overstory and understory species. This classification is presented for descriptive purposes only and our community types are not examined for potential relationships with fire severity or frequency. Using Spearman rank correlation calculations, we tested for significant differences in the frequency of non-stand replacing fire (response variable $=$ mean fire return interval) based on latitude.

\section{Results}

A total of 61 plots were inventoried. Where analysis of one or more plots within a single stand yielded matching fire history results, the plots were consolidated as a single fire history site. Thus, our 61 plots produced 55 distinct fire history sites. Eighty-eight percent of all plots in the study area contained charcoal (Table 1).

Table 1. Proportion of plots within study units that contained charcoal.

\begin{tabular}{cccc}
\hline Study Unit & Number of Plots & Plots with Charcoal & Plots with Charcoal \\
\hline Southern Oregon & 28 & 23 & $82 \%$ \\
Mount Rainier & 15 & 13 & $87 \%$ \\
North Cascades & 18 & 18 & $100 \%$ \\
Total & 61 & 54 & $89 \%$ \\
\hline
\end{tabular}

Of the 55 fire history sites, 12 sites had no fire scars or even-aged structure available for determining fire dates (Table 2). Additionally, 15 sites produced only one fire date. Of the 55 sampled sites, 28 contained fire intervals used for calculating MSAFI. Fifty-seven partial cross-sections were extracted from fire-scarred trees. We sampled 700 increment cores to estimate age classes for stand reconstruction. This yielded the identification of 101 fire dates. Of the 101 fire events, 57\% were detected from fire scar analysis and were often reinforced by stand reconstruction, while $37 \%$ were from stand reconstructions that had no evident fire scars. The remaining $6 \%$ of fire events were more recent and dated from administrative records verified by field observations (multiple standing dead trees and/or charred live survivors).

Table 2. Summary of fire history sites investigated for this study.

\begin{tabular}{ccc}
\hline & Number of Sites & Total \\
\hline No Fire Dates & 12 & $22 \%$ \\
Single Fire Date & 15 & $27 \%$ \\
Two or more Fire Dates & 28 & $51 \%$ \\
Total & 55 & $100 \%$ \\
\hline
\end{tabular}

Fire intervals varied widely throughout the study area. Intervals obtained from fire scar and age class data (28 fire history sites) ranged from 9 to 314 years, with a median of 49 years, averaging 67 years (Table 3). The whitebark pine/Douglas-fir and pinegrass communities burned most frequently (Tables 3 and 4). No fire intervals were detected from the whitebark pine/mountain hemlock or the sparse vegetation community types indicating these communities burn the most infrequently of any forests investigated. We detected fire return intervals for every 10-year class up to 160-169 years (Figure 3). For plots that showed only a single fire (incomplete interval), a majority of these fires burned more than 170 years ago indicating very low fire frequency. While most fires (67\%) occurred 
at intervals less than 100 years, $18 \%$ of plots supported evidence of only a single fire and $14 \%$ had only charcoal evidence-suggesting longer (multi-century) fires. Individual fires often fail to leave detectable evidence, or such evidence is consumed in subsequent fire events. Thus, it is possible that some fires were undetected, resulting in overestimation of fire interval lengths.

Table 3. Comparison of fire intervals and severities for each overstory forest community type.

\begin{tabular}{ccccccc}
\hline $\begin{array}{c}\text { Dominant Overstory } \\
\text { Vegetation }\end{array}$ & $\begin{array}{c}\text { No. of } \\
\text { Sites }\end{array}$ & $\begin{array}{c}\text { No. of } \\
\text { Intervals }\end{array}$ & $\begin{array}{c}\text { MSAFI }{ }^{1} \text { with } \\
\text { Range (Years) }\end{array}$ & $\begin{array}{c}\text { Median } \\
\text { (Years) }\end{array}$ & $\begin{array}{c}\text { Standard } \\
\text { Deviation (Years) }\end{array}$ & $\begin{array}{c}\text { Severity (No. } \\
\text { Fires Low/High) }\end{array}$ \\
\hline $\begin{array}{c}\text { Whitebark Pine/Douglas-fir } \\
\text { Whitebark Pine/Subalpine Fir } \\
\text { or Shasta Red Fir }\end{array}$ & 22 & 10 & $47(11-161)$ & 31 & 46 & $12 / 3$ \\
\hline $\begin{array}{c}\text { Whitebark Pine/ } \\
\text { Engelmann Spruce }\end{array}$ & 3 & 30 & $67(11-64)$ & 64 & 43 & $19 / 25$ \\
\hline $\begin{array}{c}\text { Whitebark Pine/ } \\
\text { Lodgepole Pine }\end{array}$ & 8 & 13 & $73(12-314)$ & 54 & 79 & $3 / 2$ \\
\hline Whitebark Pine (Pure Stands) & 10 & 3 & $96(38-153)$ & 97 & 58 & $5 / 5$ \\
\hline $\begin{array}{c}\text { Whitebark Pine/ } \\
\text { Mountain Hemlock }\end{array}$ & 10 & 0 & $>250$ years & - & - & $0 / 5$ \\
\hline All Sites & 55 & 59 & 67 (9-196) & 49 & 57 & $53 / 48$ \\
\hline
\end{tabular}

Table 4. Comparison of fire intervals and severities for each understory forest community type.

\begin{tabular}{|c|c|c|c|c|c|c|}
\hline Dominant Understory Vegetation & $\begin{array}{l}\text { No. of } \\
\text { Sites }\end{array}$ & $\begin{array}{c}\text { No. of } \\
\text { Intervals }\end{array}$ & $\begin{array}{l}\text { MSAFI }^{1} \text { with } \\
\text { Range (Years) }\end{array}$ & $\begin{array}{l}\text { Median } \\
\text { (Years) }\end{array}$ & $\begin{array}{c}\text { Standard } \\
\text { Deviation (Years) }\end{array}$ & $\begin{array}{l}\text { Severity (No. } \\
\text { Fires Low/High) }\end{array}$ \\
\hline Pinegrass (Calamagrostis rubescens) & 3 & 9 & $44(11-134)$ & 34 & 39 & $8 / 4$ \\
\hline Grouse Whortleberry (Vaccinium scoparium) & 20 & 25 & $55(9-196)$ & 49 & 48 & $19 / 22$ \\
\hline Common Juniper (Juniperus communis) & 3 & 5 & $64(33-140)$ & 48 & 44 & $3 / 5$ \\
\hline Greenleaf Fescue (Festuca viridula Vasey) & 5 & 9 & $84(11-164)$ & 64 & 57 & $8 / 5$ \\
\hline Dryland Grass ${ }^{2}$ & 12 & 10 & $93(13-120)$ & 65 & 86 & $11 / 8$ \\
\hline Pinemat Manzanita (Arctostaphylos nevadensis) & 4 & 1 & 130 & 130 & - & $2 / 2$ \\
\hline Sparse Vegetation & 8 & 0 & $>250$ years & - & - & $0 / 4$ \\
\hline
\end{tabular}

${ }^{1}$ Multiple Site Average Fire Interval. ${ }^{2}$ Dryland Grass was defined as a mixture of grasses that were not identified.

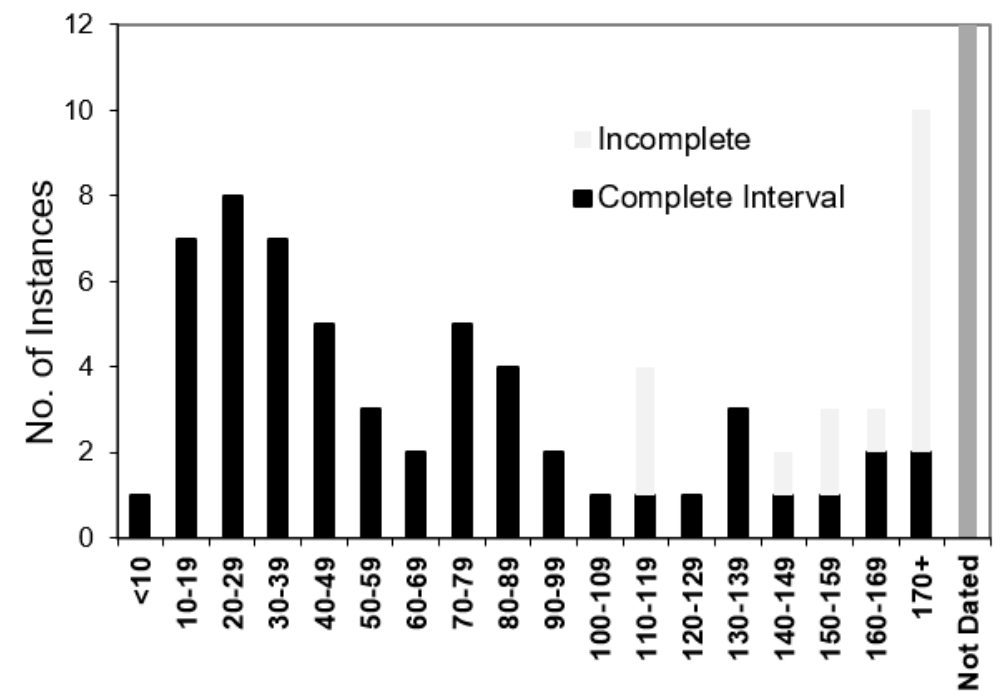

Fire Interval Range (years)

Figure 3. Distribution of fire interval classes. "Number of instances" denotes the number of individual complete intervals detected, except: 'Incomplete' denotes the number of fire history sites with only a single fire evident and are classed according to number of years since the fire date (as of 2003 or 2004), thus should be viewed as minimum values (years). Right-most bar denotes the number of sites that had inconclusive dendrochronological evidence. 
We found both low and high severity fires in all community types except whitebark pine/mountain hemlock and sparsely vegetated understories where only evidence of high severity was available (Tables 3 and 4). Forty-four percent of the most recent fire events for each site were low severity fires (Table 5). Of the 101 total fire events detected, 54\% were low severity. High severity events, reconstructed using the age class techniques, appear to occur every 100 years or more. Low severity fires burned as frequently as every nine years.

Table 5. Observed severity of most recent fire event for each site. Totals represent the entire study area.

\begin{tabular}{ccc}
\hline Study Unit & High Severity & Low Severity \\
\hline Southern & $10(56 \%)$ & $8(44 \%)$ \\
Oregon & $6(75 \%)$ & $2(25 \%)$ \\
Mount Rainier & $8(47 \%)$ & $9(53 \%)$ \\
North Cascades & $24(56 \%)$ & $19(44 \%)$ \\
Totals & & \\
\hline
\end{tabular}

The number of fires diminished during the 20th century. The period of 1800-1900 experienced 51 fire events. The period of 1900-2000 supported only 22 fire events. This represents a decrease of 57\%. Whitebark pine forests experienced a significantly lower number of fires $\left(x^{2}=13.0, p<0.01\right)$ since 1900 (Figure 4$)$. We found a modest significant negative correlation $\left(r_{\mathrm{s}}=0.453\right.$ at $\left.p=0.10\right)$ between latitude and frequency of low severity fires.

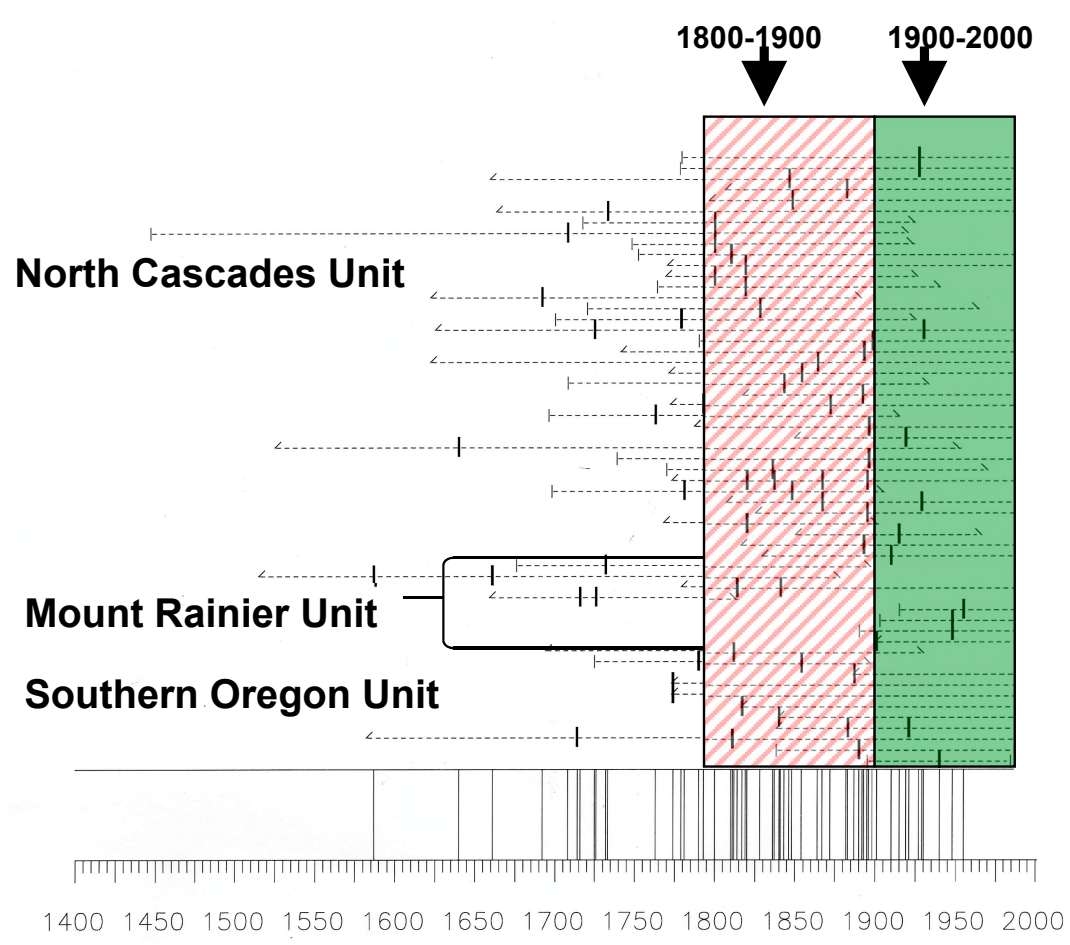

Figure 4. Master fire chronology for fire scar dates from all sites studied. Each horizontal line is an individual fire-scarred tree ring series with each vertical dash representing a dated scar.

\section{Discussion}

The wide range of intervals and mix of severities found throughout the study area and for all community types investigated reveal that fire in the whitebark pine zone is a complex agent of disturbance in the Cascade mountain range. Results indicating whitebark pine forests burned in both high and low severity events mirrors findings from the Rocky Mountains where whitebark pine are commonly associated with "mixed-severity" regimes [15,26,34]. 
The Southern Oregon Unit displayed the lowest percentage of sites with charcoal. Sites where whitebark pine and mountain hemlock co-dominate displayed very little evidence of fire. These communities are characterized by having rock, gravel, pumice, or sand as the dominant ground cover component, and situated on the Cascade crest at Crater Lake National Park where the maritime climate exhibits its strongest influence. No intervals were detected for this forest community type suggesting mountain hemlock indicates a historically low frequency and high severity regime [6].

Pure whitebark pine community types were found at 10 sites ranging the breadth of the study area. The fact that only three intervals were detected from 10 sites suggests that pure whitebark pine sites do not support frequent fire. These sites are characterized by sparse understory and overstory. In contrast to closed-canopy whitebark pine communities, there is less fuel.

The grouse whortleberry vegetation type often grows in slightly wetter and cooler environments forming a dense and continuous mat of vegetation. When conditions become favorable, grouse whortleberry aids in the spread of surface fires by increasing the flammability of litter through preheating [35]. Moreover, we observed that sites with dense grass cover had shorter intervals.

Our findings indicate that fire intervals shorten with higher latitudes in the Cascade Range. Conversely, lightning ignitions are more common at lower latitudes in the region [36]. Thus, stronger influences, such as vegetation pattern (fuel) may underlie reduced fire frequency in the south. We found comparatively less cover of both ground litter and live vegetation (forbs, grasses, and shrubs) in southern Cascade whitebark pine understories. Essentially, we propose that the variety of associated understory communities, considered as fuel types, may have a notable influence on fire frequency and perhaps severity.

A marked decline in the number of fires during the 20th century (Figure 4) may be considered a reflection of both effective agency led suppression and a cooler wetter climate during the early 1900s [37]. Acknowledging the important natural roles of fire, land managers are re-introducing fire to a variety of forest types throughout the Cascades that include whitebark pine. Fire managers may consider our findings in selecting and prioritizing target forest stands. Specifically, community types with shorter intervals (e.g., whitebark pine/Douglas-fir and pinegrass) would generally need to be burned more often if the objective is to promote fire regimes that approximate their historic intervals. Attempts to mimic historic high severity fire will likely kill healthy trees [10] that may be resistant to the non-native blister rust disease, thus critical for conservation [38]. This presents a challenge for managers who wish to maintain both fire and healthy mature trees, but fire management guidelines have emerged where conservation of this endangered tree is a priority $[39,40]$.

\section{Conclusions}

Our findings indicate that fire has been a common and complex agent of disturbance within Cascadian whitebark pine forests. Fire regimes of whitebark pine forests may be more related to site characteristics than this focal tree species exclusively. Detailed study of local climates, topography, surface fuels, and stand structures may reveal relationships with our observed spectrum of frequency and severity. In the 20th century, the number of fires diminished. Due to conservation needs, re-introducing fire should be undertaken with extreme care to avoid substantial mortality.

Acknowledgments: This research was supported by the Joint Fire Sciences Program and Crater Lake National Park. In addition, we thank Regina Rochefort, North Cascades National Park Service Complex, Laurie Kurth, formerly Mount Rainier National Park, and Keith Rowland, U.S. Forest Service for their technical and logistical support. Carol Aubry and Robin Shoal (USFS) provided valuable map information. Kathy Jope (NPS) provided office space away from Crater Lake NP. Additionally, we want to acknowledge the U.S. Forest Service Staff at; Naches Ranger District, Leavenworth Ranger District, Entiat Ranger District, Chelan Ranger District, Methow Valley Ranger District, and the Wenatchee Forest Sciences Lab for their enthusiastic support and guidance. Also thanks to project staff-Scott Weyenberg, Brenda Anderson, and Sara Worden for their tireless assistance in the field and the lab. Special thanks to Jeremy Littell and Jim Agee (University of Washington) and Henri Grissino-Mayer (University of Tennessee), and David W. Peterson (USFS) for their thoughtful assistance. Finally, thank you to the four anonymous reviewers whose suggestions significantly improved our manuscript. 
Author Contributions: M.P.M. conceived the research, acquired funding, designed and supervised field sampling and analysis. He lead the writing of this manuscript. J.S. coordinated and conducted a majority of the field sampling, lab work, and analysis. He contributed substantially to the writing of this manuscript.

Conflicts of Interest: The authors declare no conflicts of interest.

\section{References}

1. Ellison, A.M.; Bank, M.S.; Clinton, B.D.; Colburn, E.A.; Elliott, K.; Ford, C.R.; Foster, D.R.; Kloeppel, B.D.; Knoepp, J.D.; Lovett, G.M.; et al. Loss of foundation species: Consequences for the structure and dynamics of forested ecosystems. Front. Ecol. Environ. 2005, 3, 479-486. [CrossRef]

2. Tomback, D.F.; Arno, S.F.; Keane, R.E. Whitebark Pine Communities: Ecology and Restoration; Island Press: Washington, DC, USA, 2001; p. 440.

3. Schwandt, J.W.; Lockman, I.B.; Kliejunas, J.T.; Muir, J.A. Current health issues and management strategies for white pines in the western United States and Canada. For. Pathol. 2010, 40, 226-250. [CrossRef]

4. U.S. Department of the Interior, Fish and Wildlife Service (USFWS). Endangered and threatened wildlife and plants; review of native species that are candidates for listing as endangered or threatened; annual notice of findings on resubmitted petitions; annual description of progress on listing actions. Fed. Regist. 2015, 80, 80584-80612.

5. Environment Canada. Order Amending Schedule 1 to the Species at Risk Act; Canada Gazette Part II, No. 14, SOR/2012-113; Environment Canada: Toronto, ON, Canada, 2012; Volume 146.

6. United States Department of Agriculture (USDA) Forest Service. Fire Effects Information System (FEIS): Syntheses about Fire Ecology and Fire Regimes in the United States. 2018. Available online: https://www. feis-crs.org/feis / (accessed on 9 January 2018).

7. Keane, R.E.; Arno, S.F. Rapid decline of whitebark pine in western Montana: Evidence from 20-year re-measurements. West. J. Appl. For. 1993, 8, 44-47.

8. Murray, M.P.; Bunting, S.C.; Morgan, P.C. Landscape trends (1753-1993) of whitebark pine (Pinus albicaulis) forests in the West Big Hole Range, Idaho/Montana, USA. Arct. Antarct. Alp. Res. 2000, 32, 412-418. [CrossRef]

9. Tomback, D.F. Post-fire regeneration of krummolz whitebark pine: A consequence of nutcracker seed caching. Madroño 1986, 33, 100-110.

10. Keane, R.E.; Parsons, R.A. Restoring whitebark pine forests of the northern Rocky Mountains, USA. Ecol. Restor. 2010, 20, 56-70. [CrossRef]

11. Van Mantgem, P.J.; Nesmith, J.C.B.; Keifer, M.; Knapp, E.E.; Flint, A.; Flint, L. Climatic stress increases forest fire severity across the western United States. Ecol. Lett. 2013, 16, 1151-1156. [CrossRef] [PubMed]

12. Schellhaas, R.; Spurbeck, D.; Ohlson, P.; Keenum, D.; Riesterer, H. Fire Disturbance Effects in Subalpine Forests of North Central Washington. In USDA Forest Service-Region 6. Report on File at Wenatchee Forest Sciences Laboratory; USDA Forest Service: Washington, DC, USA, 2001.

13. Agee, J.K. Fire Ecology of Pacific Northwest Forests; Island Press: Washington, DC, USA, 1993.

14. Arno, S.F. The Historical Role of Fire on the Bitterroot National Forest; Research Paper INT-187; U.S. Department of Agriculture, Forest Service, Intermountain Forest and Range Experiment Station: Ogden, UT, USA, 1976.

15. Morgan, P.; Bunting, S.C. Fire Effects in Whitebark Pine Forests. In Proceedings of the Symposium on Whitebark Pine Ecosystems: Ecology and Management of a High-Mountain Resource, Bozeman, MT, USA, 29-31 March 1989; Schmidt, W.C., McDonald, K.J., Eds.; General Technical Report INT-270. U.S. Department of Agriculture, Forest Service, Intermountain Forest and Range Experiment Station: Ogden, UT, USA, 1990.

16. Barrett, S.W. Fire regimes on andesitic mountain terrain in northeastern Yellowstone National Park, Wyoming. Int. J. Wildland Fire 1994, 4, 64-76. [CrossRef]

17. Murray, M.P. Landscape Dynamics of an Island Range: Interrelationships of Fire and Whitebark Pine (Pinus albicaulis). Ph.D. Thesis, University of Idaho, Moscow, ID, USA, 1996.

18. Renkin, R.A.; Despain, D.G. Fuel moisture, forest type, and lightning-caused fire in Yellowstone National Park. Can. J. For. Res. 1992, 22, 37-45. [CrossRef]

19. Brown, J.K.; Arno, S.F.; Barrett, S.W.; Menakis, J.P. Comparing the prescribed natural fire program with pre-settlement fires in the Selway-Bitterroot Wilderness. Int. J. Wildland Fire 1994, 4, 157-168. [CrossRef]

20. Arno, S.F.; Sneck, K.M. A Method for Determining Fire History in Coniferous Forests of the Mountain West; General Technical Report INT-42; U.S. Department of Agriculture, Forest Service, Intermountain Forest and Range Experiment Station: Ogden, UT, USA, 1977. 
21. Barrett, S.W.; Arno, S.F. Increment-Borer Methods for Determining Fire History in Coniferous Forests; General Technical Report INT-244; U.S. Department of Agriculture, Forest Service, Intermountain Forest and Range Experiment Station: Ogden, UT, USA, 1988.

22. Gutsell, S.L.; Johnson, E.A. How fire scars are formed: A coupling a disturbance process to its ecological effect. Can. J. For. Res. 1996, 26, 166-174. [CrossRef]

23. Heyerdahl, E.K.; McKay, S.J. Condition of live fire-scarred ponderosa pine twenty-one years after removing partial cross-sections. Tree-Ring Res. 2017, 73, 149-153. [CrossRef]

24. Lorimer, C.G. Methodological considerations in the analysis of forest disturbance history. Can. J. For. Res. 1984, 15, 200-213. [CrossRef]

25. Keith, R.P.; Veglen, T.T.; Schoennagel, T.L.; Sherriff, R.L. Understory vegetation indicates historic fire regimes in ponderosa pine-dominated ecosystems in the Colorado Front Range. J. Veg. Sci. 2010, 21, 488-499. [CrossRef]

26. Murray, M.P.; Bunting, S.C.; Morgan, P.C. Fire history of an isolated subalpine mountain range of the Intermountain Region, United States. J. Biogeogr. 1998, 25, 1071-1080. [CrossRef]

27. Applequist, M.B. A simple pith locator for use with off-center increment cores. J. For. 1958, 56, 141.

28. Villalba, R.; Veblen, T.T. Improving estimates of total tree ages based on increment core samples. Ecoscience 1997, 4, 534-542. [CrossRef]

29. Stokes, M.A.; Smiley, T.L. An Introduction to Tree-Ring Dating; University of Chicago Press: Chicago, IL, USA; London, UK, 1968.

30. Yamaguchi, D.K. A simple method for cross-dating increment cores from living trees. Can. J. For. Res. 1991, 21, 414-416. [CrossRef]

31. Grissino-Mayer, H.D. Evaluating crossdating accuracy: A manual and tutorial for the computer program cofecha. Tree-Ring Res. 2001, 57, 205-221.

32. Brubaker, L.B. Sunrise Ridge: PIAL-ITRDB WA040. National Centers for Environmental Information, NESDIS, NOAA, U.S. Department of Commerce: Boulder, CO, USA, 1976. Available online: https:/ /www. ncdc.noaa.gov/data-access/paleoclimatology-data (accessed on 5 February 2018).

33. Peterson, D.W. Dendroecological Study of Subalpine Conifer Growth in the North Cascade Mountains. Master's Thesis, University of Washington, Seattle, WA, USA, 1993.

34. Walsh, J.R. Fire Regimes and Stand Dynamics of Whitebark Pine (Pinus albicaulis) Communities in the Greater Yellowstone Ecosystem. Master's Thesis, Colorado State University, Fort Collins, CO, USA, 2005.

35. Alexander, M.E. Estimating Fuel Weights of Two Common Shrubs in Colorado Lodgepole Pine Stands; Research Note RM-354; U.S. Department of Agriculture, Forest Service, Rocky Mountain Forest and Range Experiment Station: Fort Collins, CO, USA, 1978; p. 4.

36. Rorig, M.; Ferguson, S.A. Characteristics of lightning and wildland fire ignition in the Pacific Northwest. J. Appl. Meteorol. 1999, 38, 1565-1575. [CrossRef]

37. Gedalof, Z.; Smith, D.J. Interdecadal climate variability and regime scale shifts in Pacific North America. Geophys. Res. Lett. 2001, 28, 1515-1518. [CrossRef]

38. Keane, R.E.; Tomback, D.F.; Aubry, C.A.; Bower, A.D.; Campbell, E.M.; Cripps, C.L.; Jenkins, M.B.; Mahalovich, M.F.; Manning, M.; McKinney, S.T.; et al. A Range-Wide Restoration Strategy for Whitebark Pine (Pinus albicaulis); General Technical Report RMRS-GTR-279; U.S. Department of Agriculture, Forest Service, Rocky Mountain Research Station: Fort Collins, CO, USA, 2012; p. 108.

39. Keane, R.E.; Quinn, D.; Cochrane, J. Guidelines and Best Practices for Managing Fire in Whitebark Pine Stands in the Crown of the Continent; US Forest Service Rocky Mountain Research Station, Missoula Fire Sciences Laboratory: Missoula, MT, USA, 2017; p. 25.

40. Perkins, D.L.; Means, R.E.; Cochrane, A.C. Conservation and Management of Whitebark Pine Ecosystems on Bureau of Land Management Lands in the Western United States; Technical Reference 6711-1; Bureau of Land Management: Denver, CO, USA, 2016; p. 93.

(C) 2018 by the authors. Licensee MDPI, Basel, Switzerland. This article is an open access article distributed under the terms and conditions of the Creative Commons Attribution (CC BY) license (http:/ / creativecommons.org/licenses/by/4.0/). 